충북 진천 송두리 유적 출토 노벽의 재료과학적 분석

\title{
Materials Analysis of Furnace Wall Excavated from Songdu-ri Site in Jincheon, Chungbuk
}

\author{
장원진, 한민수 \\ 한국전통문화대학교 문화유산전문대학원 문화재수리기술학과 \\ Won Jin Jang, Min Su Han ${ }^{*}$ \\ Dept. of Heritage Conservation and Restoration, Graduate School of Cultural Heritage, Korea National University of Cultural \\ Heritage, Buyeo, 33115, Korea
}

Received September 21, 2020

Revised October 09, 2020

Accepted October 13, 2020

\section{*Corresponding author}

E-mail: dormer@nuch.ac.kr

Phone: +82-42-830-7381

Journal of Conservation Science 2020;36(5):421-429

https://doi.org/10.12654/JCS.2020. 36.5.11

pISSN: 1225-5459, eISSN: 2287-9781

(c) The Korean Society of Conservation Science for Cultural Heritage

This is an Open-Access article distributed under the terms of the Creative Commons Attribution Non-Commercial License (http://creativecommons.org/ licenses/by-nc/3.0) which permits unrestricted non-commercial use, distribution, and reproduction in any medium, provided the original work is properly cited.
초 록 본 연구는 진천 송두리 유적에서 출토된 노벽을 대상으로 총 11 개의 층위별로 물리화학적인 분석을 실시하여 노벽의 층위 간 재료학적 차이 및 제작방법을 추론하였다. 미세조직 관찰 결과, 출토 노벽의 층위는 크게 3 개의 그룹으로 나누어지며, 1 층은 과소성층, $2 \sim 9$ 층은 일부 피열이 관찰되는 소성층, $10 \sim 11$ 층은 비소성 토양층으로 구분되었다. 입도분석 결과, 소성층은 굵은 모래의 함량이 비소성층에 비해 상대적으로 높았고, 곡률계수 분석결과에서도 차이를 확인하였다. 구성광물 분석 결과, 전체적인 XRD 회절 패턴은 유사하나 저온성 광물과 고온성 광물의 강도가 층위 간 차이가 발생하여 피열의 정도가 달랐으며, 열분석 결과에서 1 층과 2 층에서만 뮬라이트 발열피크가 발견되지 않아 최종적으로 사용된 층위로 추정하였다. 결과적으로 노벽의 층위 간 재료학적 차이가 크지 않아 노벽 제작 시 기존 주변의 토양과 성분이 유사한 점토를 사용하여 축로하였을 것으로 판단 되나, 층위 간 구성입자의 형상과 특징이 일부 다른 것으로 보아 수비를 하거나 석립을 일부 첨가했을 가능성이 있다.

중심어 노벽, 제철로, 수비, 축로

ABSTRACT This study examined the manufacturing process of a furnace wall excavated from the Songdu-ri Site in Jincheon, and the difference in material composition between the 11 layers of the wall using physicochemical analyses. Based on microstructure observations, these layers could be largely divided into three groups: an undercalcined first layer, calcined second to ninth layer with evidences of partial heat, and non-fired soil layers from the tenth to the eleventh layer. Particle size analyses revealed that the fired layer constituted a relatively higher content of coarse sand than the non-fired layer. This difference was further confirmed by the results of the curvature coefficient analysis. An analysis of the constituent minerals showed similar overall XRD diffraction patterns between the different layers, but variations in the intensity of the low-temperature and high-temperature minerals. This indicates that the degree of heat was different. The thermal analysis results demonstrated that the heating peak of mullite was only reached in the first and second layers of the wall, thus implying these as the layers to be finally used. Consequently, no significant difference could be observed between the materials of the various layers of the wall. Thus, it can be suggested that the furnace wall was constructed using clay, which had a composition similar to that of the soil present in the area. However, the shape and characteristics of the constituent particles between the layers displayed partial variations, and it is possible that some external materials might have been added.

Key Words Furnace wall, Iron furnace, Separate of particles, Making furnace wall 


\section{1. 서 론}

인류는 철을 이용해 도구를 제작, 사용하게 되면서 이 전 시대보다 한층 풍요롭고 발전된 사회를 이룩하였다. 현대에서도 제철 기술이 그 나라의 기술 수준을 가늠하는 척도가 되듯이 고대 사회에서도 철기 생산 기술은 국가 경쟁력을 높이고 타 국가와의 경쟁에서 우위를 점할 수 있게 해준 중요한 요소였으며 현재까지도 지속적인 기술 의 발전이 일어나고 있는 지금은 철의 시대라고 해도 과 언이 아니다(Jungwon National Research Institute of Cultural Heritage, 2018).

고대의 제철기술을 연구하기 위해서는 최종 결과물인 철제품을 분석하는 것이 가장 확실하지만 수량의 한계, 유물의 시료 채취가 어려운 점, 부식에 의한 손상 등으로 인해 여러 제한이 따른다. 때문에 제철유적에서 출토되는 슬래그 및 노벽의 자연과학적 연구는 철제품을 훼손시키 지 않고 해당 유적의 성격을 규명할 수 있는 유효한 자료 로 많이 활용되었다. 즉, 제철공정 및 시설을 분석함으로 써 해당 유물과 유적의 손상 없이 제철유적의 기술적 특 징과 조업의 성격을 파악하는데 사용된 것이다(Jungwon

National Research Institute of Cultural Heritage 2016; 2018).

위와 같은 관점에서 노벽은 슬래그, 철괴 등과 함께 제 철로의 성격을 규명하는 장치로 사용되어왔고 유적마다 특성을 파악하는데 유효한 자료로 활용되었다. 하지만 이 같은 연구는 노벽을 독립적인 하나의 문화재로 본 것이 아니라 성격 규명의 수단 중 하나로 소비하였다. 기존의 연구와 논문을 검토해본 결과 슬래그 및 철괴 등에 비해 연구된 역사가 현저하게 짧으며 그 사례가 적다. 중국의 경우 시대에 따라 발전하는 제련로의 형태와 재료에 대한 현장 조사와 과학적 분석이 결합된 상세한 연구(Liu, 2017)가 진행되었으며, 제철로 주재료가 점토에서 암석으 로 변화함을 밝혔고, 보수 재료에서도 점토 매트릭스의 비율, 개재물, 공극율의 차이를 확인하고 이를 통해 제련 로 재료의 역사적 발전상과 제철기술에 대한 고찰을 진행 하였다. 국내의 경우, 다수의 논문(Cho, 2013; Hong, 2015; Lee et al., 2015)에서 함께 발굴된 철재 슬래그등과 어떻 게 영향을 주고받았는지, 성분분석을 통해 내식성을 고려 한 재료인지, 노의 온도가 어디까지 상승하였는지 등을 고찰하였으나, 1 2점의 노벽 재료만 분석을 진행하고, 결과를 도출하는 것을 확인할 수 있었다.

하지만 이는 층위가 구분되는 노벽의 특성을 고려했을 때 특정 층위를 노벽 전체의 특징으로 결론짓는 오류를 범할 수 있으며, 때문에 노벽의 특성을 고려한 시료 선정 및 과학적 분석이 필요하다. 따라서 이번 연구는 충청북
도 진천 송두리 유적 출토 노벽의 자연과학적 분석을 통 해 재료학적인 접근을 실시하고 층위에 따른 물리화학적 특성 변화를 파악고자 한다. 층위의 구성에 사용된 재료, 층위 간 재료 특성 변화 유무, 어떠한 피열 특성을 통해 층위를 구성하는 광물이 변화하였는가 등을 연구하여 송 두리 유적 노벽의 제작기술을 확인하는 것이 이번 연구의 목적이다. 또한 이러한 연구들이 축적되면 향후 타지역 출토 노벽과의 비교를 통한 지역 간 노벽 제작 기술간 상 관성 분석을 실시할 수 있을 것으로 전망한다.

\section{2. 재료 및 방법}

\section{1. 연구재료}

본 연구에서 분석한 노벽은 충청북도 진천 송두리 유 적 출토 노벽이다(Figure 1). 진천은 청원, 충주, 보은, 청주 와 함께 중원지역 제출유적의 대표적인 지역으로 시·발 굴 조사를 통해 제철 관련 유적이 확인되고 있다. 송두리 유적은 청동기 시대부터 조선 시대까지 다양한 형태의 유 구들이 조사되었다. 발굴 조사에 따라 송두리 유적에서는 제련로와 단야로 등 모두 56기의 제철유구가 조사되었으 며, 특히 해당 노벽 시료가 출토된 4지점은 남쪽 지역 구 하도 주변으로 제철단지가 조성되었던 것으로 보이며, 이 곳에는 제련로와 단야로를 비롯해 작업장과 집수시설, 배 수시설 등 매우 집약적인 형태의 생산이 이루어진 것으로 추정된다. 인근 지역 유적들인 진천 석장리, 구산리의 운 영 시기는 4세기대로 편년되고 있는 것에 비해(Cheongju National Museum, 2001; 2004), 진천 송두리 유적 제철유구 는 인근 토기가마의 형태, 출토 유물의 편년 등을 통해 백제 이전에 존재했던 진천지역 일대의 지역 집단이 운영 했던 것(Central Institute of Cultural Heritage, 2020)으로 추 정된다. 따라서 해당 노벽의 분석을 통해 원삼국 시대의 제철기술 수준을 파악할 수 있을 것으로 판단된다.

분석 대상인 노벽은 4-1지점 13호 제련로 출토 노벽으 로 해당 호는 외경은 $140 \mathrm{~mm}$, 내경은 $111 \mathrm{~mm}$, 깊이는 61 $\mathrm{mm}$ 인 반지하식 원형로이다. 해당 노에서 획득한 분석 시 료는 육안으로 식별되는 11 개의 층위가 존재하였고 약 33 $\mathrm{cm}$ 의 길이로 구성되어 있다. 각 층위별로 물리화학적 특 성을 파악하기 위해 시료를 층위별로 채취하여 분석을 진 행하였다. 피열로 인해 광물의 변화가 크게 발생하였다고 판단되는 1 층과 2 층은 시료를 추가적으로 채취하였다. 


\section{2. 연구방법}

노벽의 색은 소성 온도, 소성 시간, 소성 분위기 및 원 료 물질의 화학조성에 영향을 받으며, 따라서 색 정보를 통해 소성도 및 소성 환경을 유추할 수 있다. 색차측정기 (CR-400, Minolta, JPN)를 이용하여 노벽의 표면에 직접 접촉해 측정하였고, 가장 위층인 1층 시료만 따로 떼어내 세척한 후 측정하였다. 측정 시 오차를 줄이기 위하여 3회 측정 후 평균값을 사용하였다. 색도 값은 $a^{*}$ (초록-빨강), $b^{*}$ (노랑-파랑), $L^{*}$ (명도)로 표시하는 $\mathrm{CIE} \mathrm{LAB}$ 색공간을 이용해 도시하였다. 기공과 입자의 분포 및 크기, 색상, 구성광물, 노의 재사용 흔적 등을 확인하고자 마운팅 시 편을 제작하여 편광현미경(Eclipse lv100n pol, Nikon, JPN) 에서 미세조직을 관찰하였으며, 이미지 분석을 통해 정량 적인 기공률에 대한 분석 결과도 도출하였다. 구성광물을 확인하고자 시료홀더에 분말화한 시료를 담아 X-선회절 분석기(Smart Lab, Rigaku, JPN)를 이용하여 결정구조를 분석하였다. 분석 조건은 $40 \mathrm{kV}, 40 \mathrm{~mA}, 5^{\circ} \sim 80^{\circ}, 2^{\circ} / \mathrm{min}$ 이 며, Spinner stage를 이용하여 분석하였다. 개별 입자의 크 기 분포를 측정하기 위해 입도분석을 실시하였으며, 습식

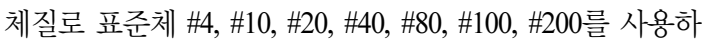
여 체분석을 실시하고, 표준체 \#200 통과분에 대하여 레이 저입도분석기(Bettersizer S3 Plus, Bettersize, $\mathrm{CHN}$ )로 분석 하였다. 체분석과 레이저분석에 의한 입도분석결과를 종
합하여, 통일분류법(Unified Soil Classification System, USCS)에 의해 입도를 자갈 $(>4.75 \mathrm{~mm})$, 굵은 모래 $(4.75 \sim$ $0.425 \mathrm{~mm})$, 가는 모래 $(0.0425 \sim 0.075 \mathrm{~mm})$, 실트 $(0.075 \sim$ $0.002 \mathrm{~mm})$, 점토 $(<0.002 \mathrm{~mm})$ 로 분류하였으며, 시료별 입 도분포곡선을 작성하였다. 유리질화가 심하게 되어 입도 분석을 진행하기 어렵다고 판단된 1 층의 시료를 제외하 고 분석을 진행하였으며, 각각 누가통과율이 $10 \%, 30 \%$, $60 \%$ 에 해당하는 입경을 계산하여 균등계수와 곡률계수 를 산출하여 양입도의 조건을 만족하는지 확인하였다. 열 적 특성을 확인하기 위하여 시차열중량분석기(SDT 650, Ta instrument, USA)를 이용하여 분석을 실시하였으며, 분 석 조건은 온도범위 $25 \sim 1200^{\circ} \mathrm{C}$, 승온속도는 $20^{\circ} \mathrm{C} / \mathrm{min}$ 로 하였다.

\section{3. 연구 결과}

\section{1. 색도}

충청북도 진천 송두리 유적 출토 노벽의 색도를 측정 하여 표로 나타냈다(Figure 2, Table 1). 전체적으로 명도는 $44 \sim 64$ 의 범위를 가지며, $a^{*}$ 값은 2 9, $b^{*}$ 값은 10 27의 범위를 가졌다. 층위 간 색도값이 특정 범위에 분포되어 있지 않고 산재되어 있는 것을 확인할 수 있었으며, 이는 기본적인 구성 원료가 유사하고, 피열에 의한 색상 변화
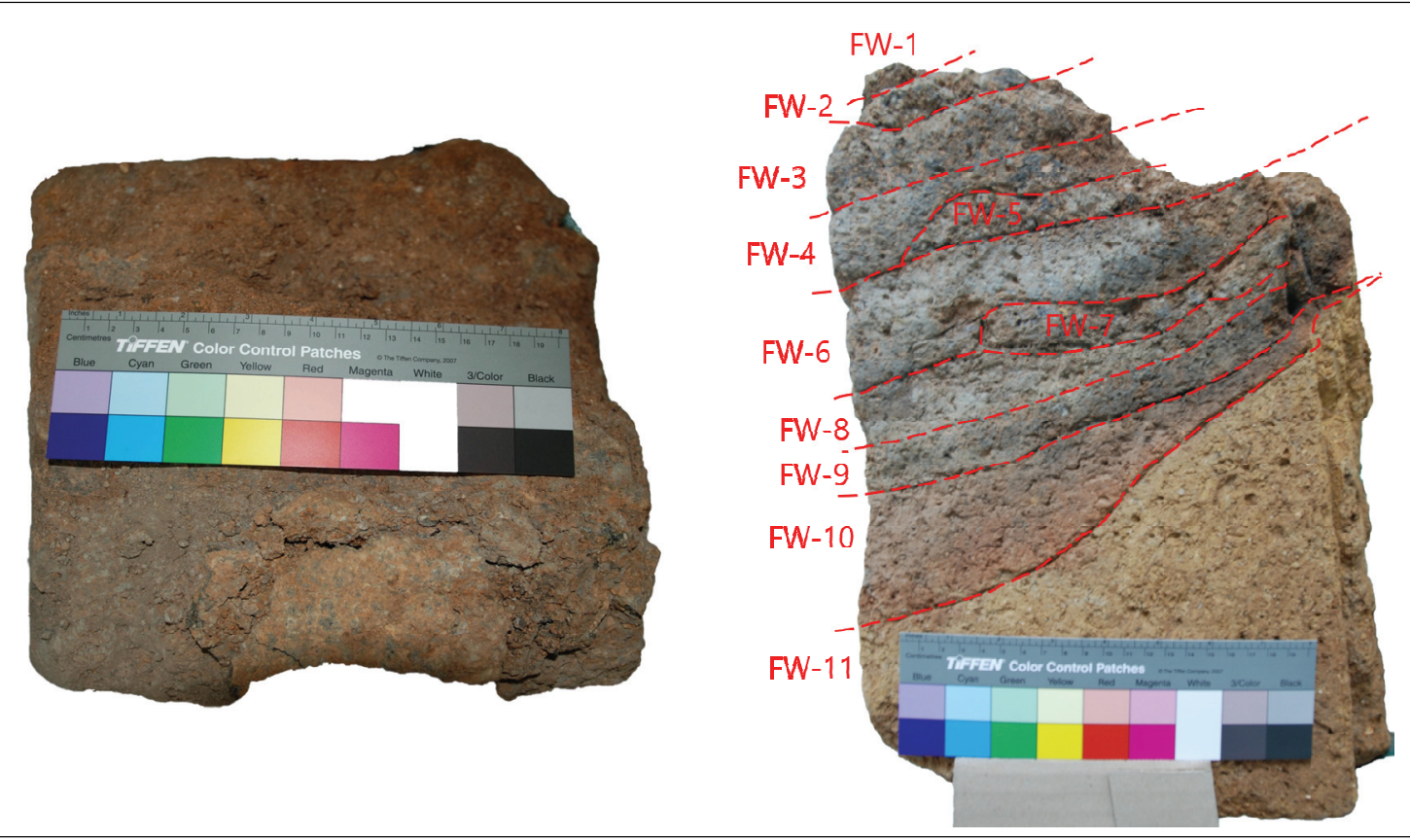

Figure 1. Picture of furnace wall from Songdu-ri Site in Jincheon. 
의 차이가 있는 것으로 보인다. 또한 직접 피소성과 흑색 탄화물의 부착으로 인하여 1층으로 올라갈수록 명도 값 이 감소하는 경향이 나타났다.

Table 1. Results of color measurement of Furnace walls

\begin{tabular}{cccc}
\hline Sample & $\mathbf{L}^{*}$ & $\mathbf{a}^{*}$ & $\mathbf{b}^{*}$ \\
\hline FW-1 & 45.77 & 4.25 & 13.50 \\
FW-2 & 49.41 & 5.74 & 15.81 \\
FW-3 & 56.02 & 3.06 & 13.21 \\
FW-4 & 48.97 & 4.38 & 14.21 \\
FW-5 & 54.44 & 2.11 & 10.54 \\
FW-6 & 51.41 & 6.82 & 17.45 \\
FW-7 & 52.98 & 4.22 & 15.44 \\
FW-8 & 58.95 & 2.6 & 14.36 \\
FW-9 & 55.66 & 5.14 & 17.58 \\
FW-10 & 57.49 & 8.76 & 20.11 \\
FW-11 & 61.37 & 8.31 & 26.47 \\
\hline
\end{tabular}

\subsection{1. 미세조직}

노벽의 11 개의 층위는 크게 3 종류의 층으로 분류되었 다. 직접적인 피열로 인해 과소성이 일어난 층으로 보이 는 1층, 간접 피열로 인해 소성이 일어난 것으로 보이는 2 9층인 소성층, 피열을 상대적으로 받지 않은 것으로 보이는 $10 \sim 11$ 층인 비소성층이다(Figure 3). 모든 층에서 크고 작은 석영 입자와 백색 광물 등이 관찰되었고 각 층
위별로 색상과 구성입자가 특징적으로 나타났다.

과소성된 1 층의 단면관찰 결과, 전체적으로 고온으로 유리질화 되었으며, 확장된 기공이 다수 존재하는 것을 확인하였다. 또한 피열로 인해 생성되는 블로팅 현상 등 이 관찰되며, 상대적으로 다양한 색상을 띠는 것이 특징 이다. 다른 층에서는 관찰되지 않는 침상의 결정형도 존 재한다.

소성층인 2 9층까지의 현미경 관찰 결과, 1 층에서 보 이던 자색의 광물과 침상결정형의 광물이 사라지는 것을 확인했다. 전체적으로 색감이 어두워지고 단순해진다. 이 는 노의 조업 과정 중에 생성된 탄화물 증착으로 인한 변 색으로 추정된다. 구성입자는 과소성층에 비해 크기가 감 소하였으며 과소성층과 마찬가지로 석영 입자가 산재하였 으나 상대적으로 분포 비율이 높아진 것을 알 수 있다.

비소성층인 10 11층의 현미경 관찰 결과, 소성층에서 보이던 흑색의 입자가 11 층으로 갈수록 적어지는 것을 확 인했다. 황색의 입자로 구성되어 있는 층이며, 소성층과 마찬가지로 불규칙하게 석영 입자가 산재되어 있으며 입 자의 크기가 작다. 소성층과 색상에는 큰 차이가 있으나, 층위를 구성하는 입자의 크기나 분포는 유사한 것으로 보 이며, 이는 유적지의 원 퇴적층일 가능성이 높다.

\subsection{2. 이미지 분석}

이미지 분석은 촬영한 이미지를 바탕으로 기공률과 기 공의 영역을 정량적으로 파악하는 분석이다. 이미지의 Intensity를 기반으로 기공을 특정하였으며, 오차를 줄이
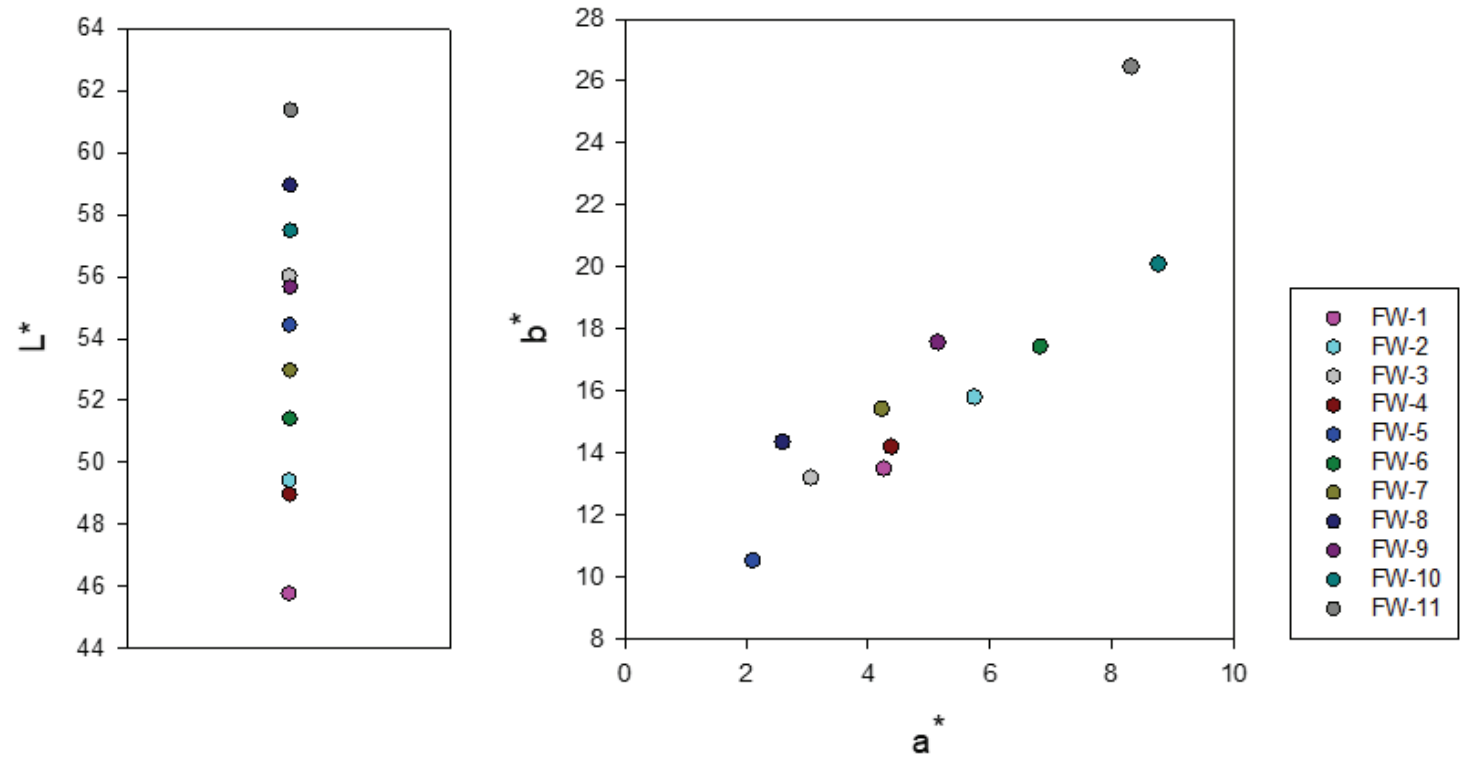

Figure 2. Color plot graph of furnace wall excavated from Songdu-ri site. 

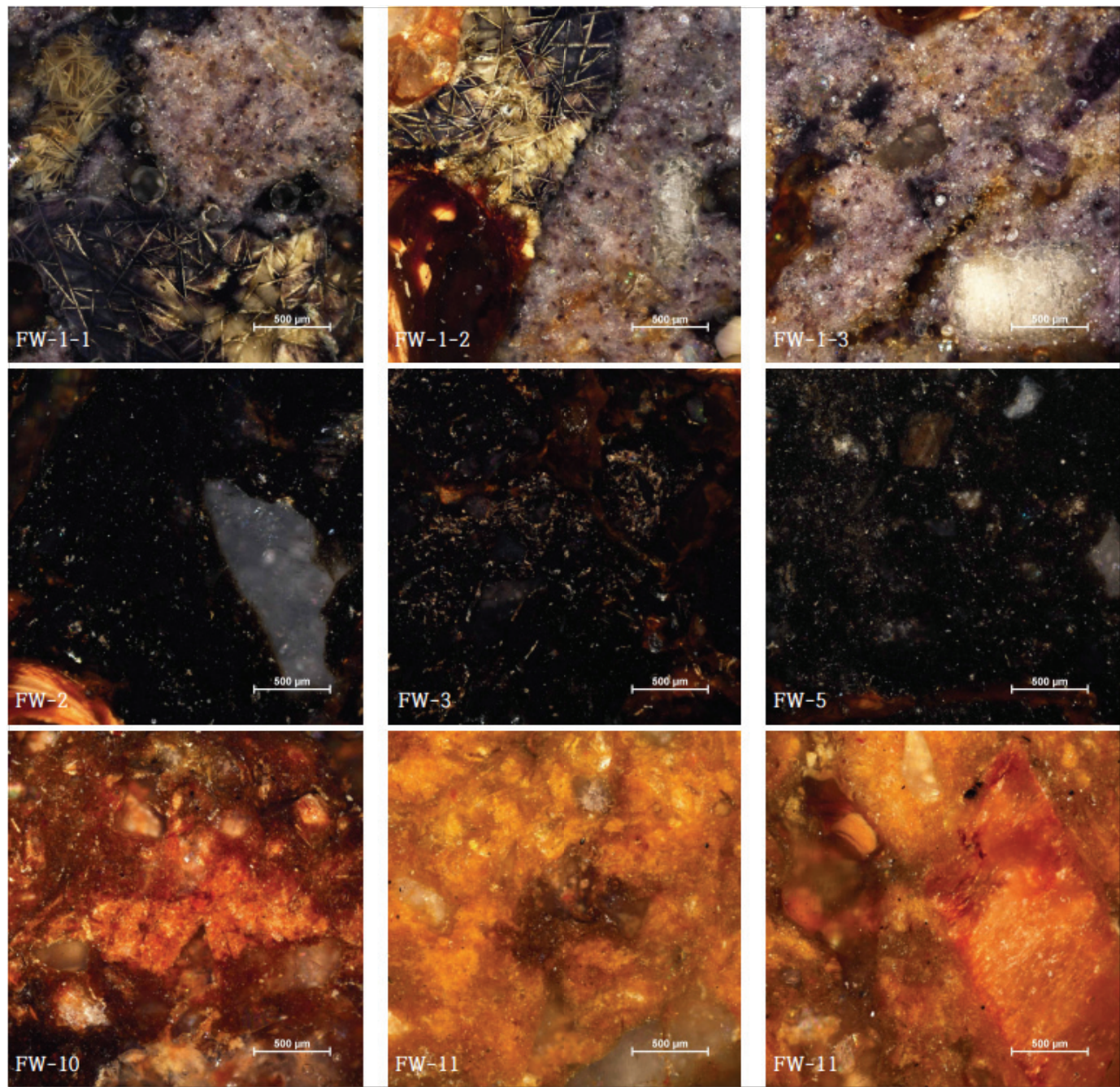

Figure 3. Microscopic images of different layers of the furnace wall.

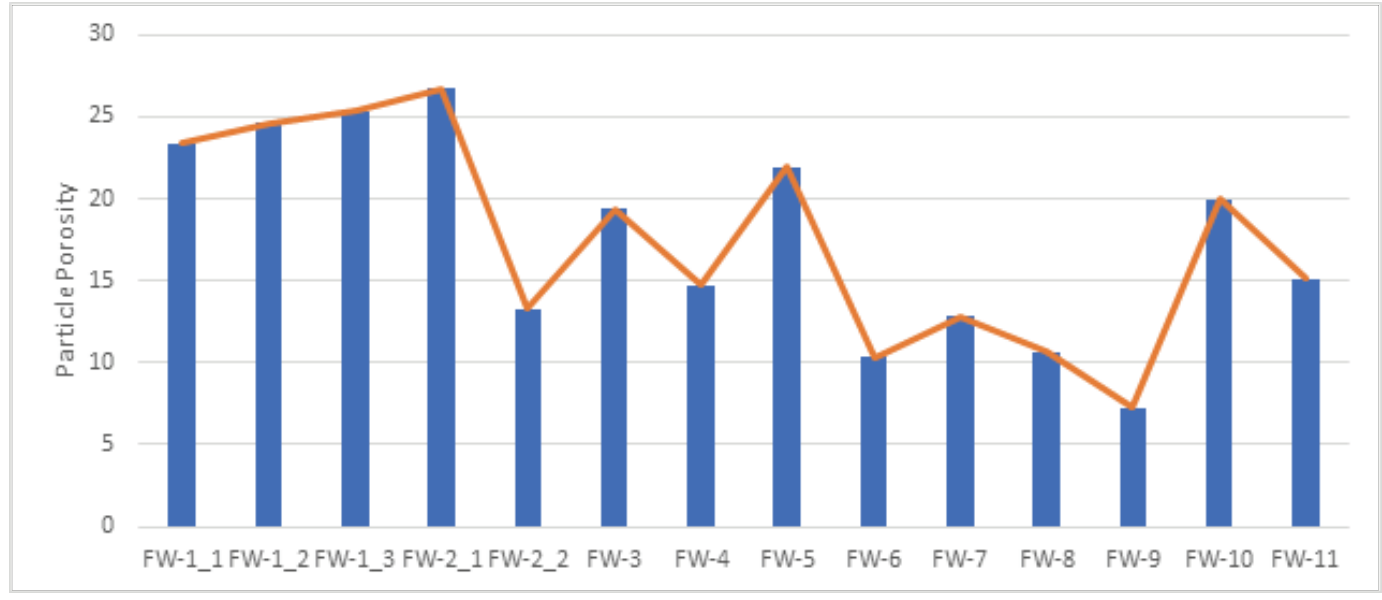

Figure 4. Particle porosity graph for each layer of the furnace wall. 
기 위해 각 층마다 3 장 이상의 사진을 선택하여 분석을 실시하였다.

이미지 분석 결과, 1 층부터 9 층으로 갈수록 기공률이 상 대적으로 서서히 감소하는 경향이 확인되었다. 특히, 1 2 층은 거의 유사한 기공률을 보였으며, 이는 유사한 재료 가 유사한 피열환경에 노출됨으로써 보이는 특징으로 추 정된다. 또한 $1 \sim 9$ 층에서 보이는 특징은 이들 층위가 인 위적으로 조성된 것임을 알 수 있고, 비소성층인 10 층과 11 층에서는 다시 소폭 증가하는 것으로 보아 1 9층과 다 른 과정을 겪은 층위임을 추정할 수 있었다(Figure 4).

\section{2. 광물조성}

분석 대상 시료에 대한 X-선 회절분석 결과, 모든 노벽 시료에서 일반적인 토양에서 검출되는 석영(Quartz), 장석 (Feldspar) 등이 확인되었으며, 특히 장석 피크의 강도는 1 층으로부터 11 층으로 갈수록 강해졌다. 소성이 진행된 것으로 보이는 $1 \sim 9$ 층까지의 시료에선 헤르시나이트 (Hercynite)와 뮬라이트(Mullite)가 관찰되었으며, 강도가 9 층으로 갈수록 감소하는 경향을 보이며 비소성층에서는 관찰되지 않는다. 또한 과소성층에서는 백운모 (Muscovite)가 확인되지 않았으며, 소성층인 2-2층과 8층 에서는 확인되지 않았다. 점토광물인 딕카이트(Dickite) 피크는 소성층의 일부 시료에서 관찰되며, 비소성층에서 강한 강도로 나타난다(Figure 5).

결과적으로 과소성층과 소성층은 피열에 의해 저온성 광물이 소멸되거나 상대적으로 적은 양이 남아있으며, 고 온성 지시광물이 존재함을 알 수 있다. 또한 비소성층인 10 층과 11 층의 시료는 과소성층과 소성층의 시료와 재료 적으로 차이가 있으나, X-선 회절패턴이 유사하고 소성층
과도 구성광물의 차이가 크지 않아 다른 열적 특성을 겪 은 층으로 추정된다.

\section{3. 입도분석}

입도분석 결과, 노벽의 소성층인 2 9층의 시료는 비 소성층 시료에 비해 굵은 모래의 함량이 $50 \%$ 부근으로

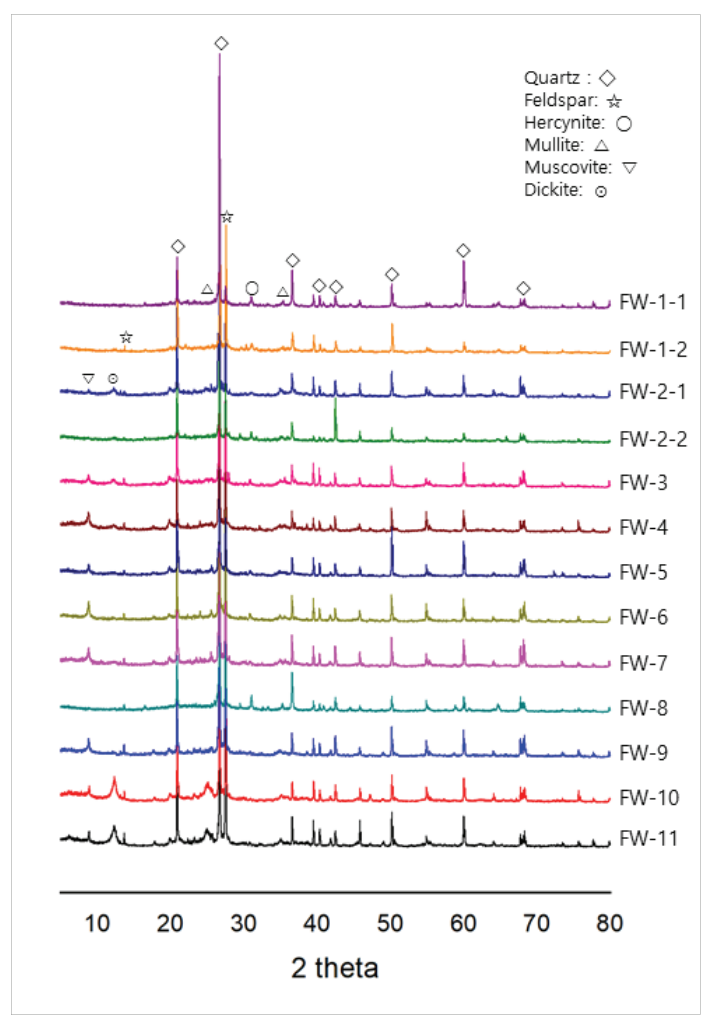

Figure 5. X-ray diffraction patterns of samples for the furnace wall.

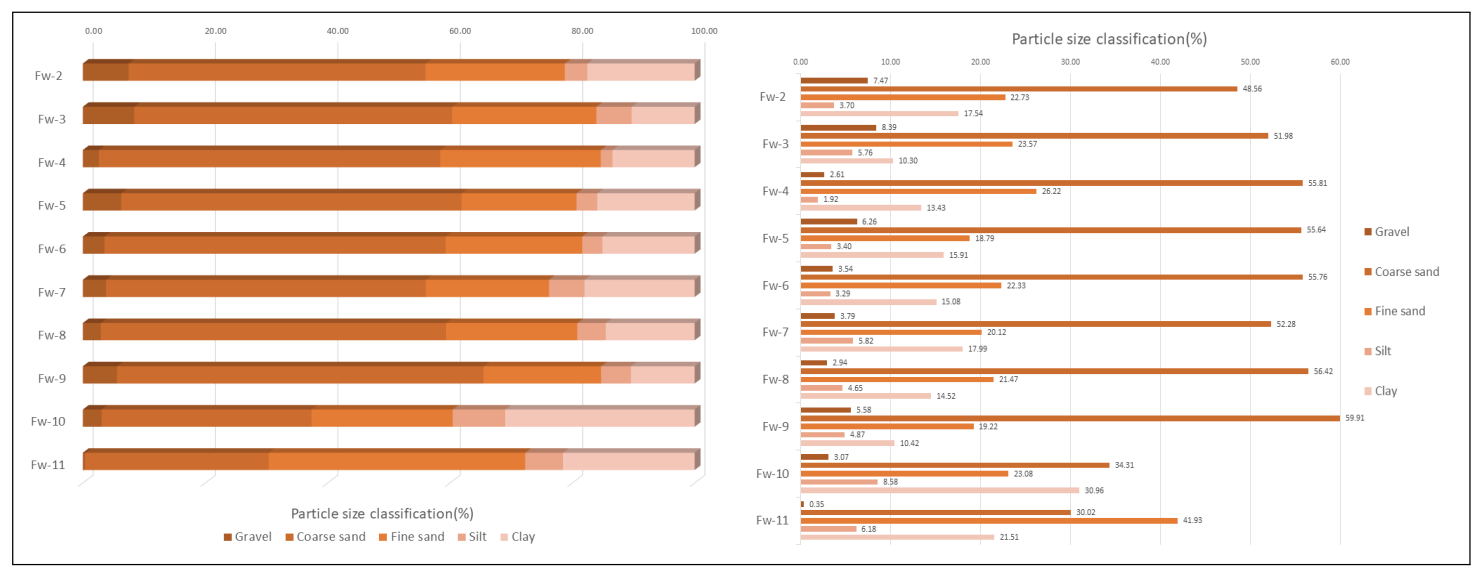

Figure 6. Receiving classification for each sample of the furnace wall. 


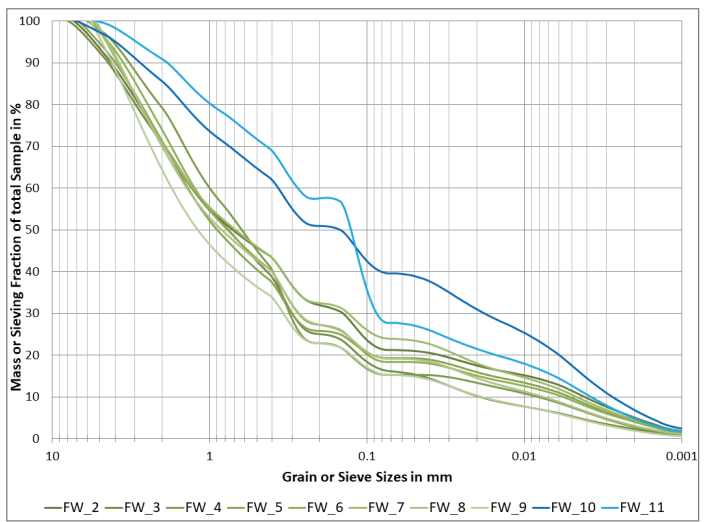

Figure 7. Grain-size distribution curve for each sample of the furnace wall.

높게 형성되어 있었으며 자갈의 함량 또한 4층과 9층을 제외하고 모두 비소성층보다 높은 것을 확인할 수 있었 다. 비소성층은 상대적으로 가는 모래 이하의 입경에서 소성층보다 높은 함량을 보였고 이러한 결과를 종합해볼 때 소성층과 비소성층의 구성 재료는 차이를 보이는 것으 로 판단된다(Figure 6,7).

또한 균등계수와 곡률계수를 산출하여 양입도의 조건 을 각층이 만족하는지 확인하였다. 결과적으로 모든 층이 양입도의 조건을 만족하지는 않았으나 비소성층인 10 과 11 층의 시료만 곡률계수가 1미만으로 다른 층과 큰 차이 를 보였다(Table 2).

\section{4. 열분석}

출토 노벽의 열분석 결과, 소성유무와 관계없이 $573^{\circ} \mathrm{C}$ 에서 일어나는 석영의 상전이가 확인되었다. 1 층의 시료
와 2 층 시료 일부에서 $900^{\circ} \mathrm{C}$ 부근의 뮬라이트 발열 피크 가 존재하지 않거나 미약한 것으로 보아 상대적으로 고온 을 경험한 것을 확인했다. 그 외의 모든 층에선 뮬라이트 발열 피크가 발견되는 것으로 보아 상대적으로 피열을 적 게 받은 것으로 보인다(Figure 8).

\section{4. 결론 및 고찰}

본 연구에서는 진천 송두리 유적에서 출토된 노벽의 층위 간 특성을 분석하여 고대 노벽의 재료학적 특징과 축로기술을 추정하고자 하였다. 그 결과를 정리하면 다음 과 같다.

1. 색도 측정 결과, 층위 간 경향성이 뚜렷하진 않으나 색도차이가 존재하고 과소성층인 1 층으로 갈수록 명도가 감소하는 경향이 존재하였다. 회청색으로 소결된 과소성 층은 구성하는 입자의 크기와 색상이 다양하였다. 소성층 은 모두 흑색 탄화물이 부착되어 현미경 상에서 유사한 색상을 보였고 층위를 구성하는 입자의 크기나 형태 등이 매우 유사하였다. 비소성층의 색상은 밝은 황토색으로 소 성층과 구별되고 입도분석 결과에 따라 입도분포의 차이 가 있었다.

2. 과소성층은 기공의 형태와 크기가 소성층과 비소성 층에 비해 크고 원마도가 좋았다. 고온으로 피열을 받아 형성된 블로팅 현상이 관찰되었고 이미지 분석 결과, 상 대적으로 높은 기공률을 보였다.

3. X-선 회절분석결과 비소성층으로 갈수록 고온지시 광물이 존재하지 않음을 확인했다. 또한 비소성층에서 강 한 강도로 나타나는 딕카이트 피크는 소성층에 비해 열적 특성변화를 적게 경험한 것으로 추정된다. 열분석 결과,

Table 2. Particle diameter and uniformity coefficient and curvature coefficient of furnace wall

(Unit: $\mathrm{mm}$ )

\begin{tabular}{cccccc}
\hline & D 10 & D 30 & D 60 & Uniformity coefficient & Coefficient of gradation \\
\hline FW-2 & 0.004 & 0.141 & 1.295 & 323.75 & 6.436 \\
\hline FW-3 & 0.020 & 0.299 & 1.284 & 64.2 & 5.740 \\
\hline FW-4 & 0.008 & 0.310 & 0.996 & 124.5 & 11.964 \\
\hline FW-5 & 0.005 & 0.301 & 1.374 & 274.8 & 24.897 \\
\hline FW-6 & 0.006 & 0.273 & 1.245 & 207.5 & 15.465 \\
\hline FW-7 & 0.005 & 0.132 & 1.28 & 256 & 4.461 \\
\hline FW-8 & 0.008 & 0.269 & 1.394 & 174.25 & 11.168 \\
\hline FW-9 & 0.018 & 0.340 & 1.739 & 96.611 & 0.040 \\
\hline FW-10 & 0.003 & 0.018 & 0.366 & 122 & 0.520 \\
\hline FW-11 & 0.004 & 0.087 & 0.275 & 68.75 & \\
\hline
\end{tabular}




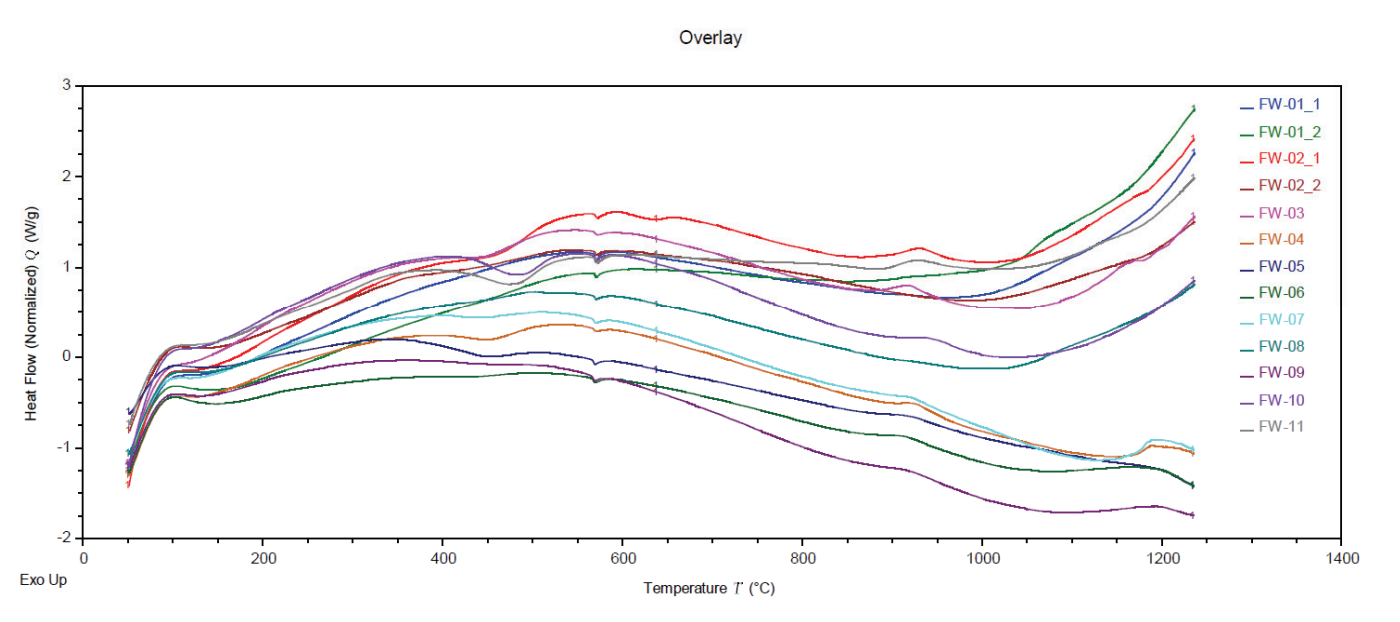

Figure 8. Differential thermal analysis graph for each sample of the furnace wall.

$900^{\circ} \mathrm{C}$ 부근에서 나타나는 뮬라이트의 발열 피크가 과소 성층인 1 층과 소성층인 2 층 일부에서만 존재하지 않는 것 으로 보아 과소성층과 2층 일부 시료는 고온으로 피열된 경험이 있음을 나타냈다.

4. 회청색의 소결면 중첩현상만으로 노벽의 보수가 이 루어졌다고 단정하는 것은 경계해야 한다(Shin, 2018). 그 러나 전체적으로 노벽에서 회청색 소결면의 중첩현상과 헤르시나이트의 관찰이 반복되는 점을 보았을 때 용융된 상태의 철 함유물질이 노벽 내부에 영향을 끼쳤을 가능성 은 높아보이므로 노의 보수를 통해 재사용했을 가능성이 높다.

이 같은 결과를 바탕으로, 송두리 유적 노벽의 주재료 는 점토이며, 보수재료 또한 재료학적으로 유사한 특성을 갖는 점토를 사용했을 것으로 추정된다. XRD 결과를 보 았을 때 비소성층와 소성층 간 구성광물의 차이가 크지 않으며 특정 피크가 반복적으로 관찰된다. 열분석 결과에 서 1 층과 일부 시료에서만 고온 피크가 존재하지 않는 것 은 소결된 층은 제거된 후 재사용되었기 때문으로 추정되 며, 최종적으로 노벽이 사용된 1 층과 2 층의 시료만 고온 으로 피열된 것으로 보인다. 미세조직 관찰결과 또한 과 소성층이 다른 층위들에 비해 기공의 형태나 크기가 크고 기공율이 높아, 열분석의 소결과 같은 결론을 도출할 수 있다. 입도분석 결과에서 소성층과 비소성층의 입도 함량 차이가 발생하는데, 이는 원퇴적층에 비해 내화성을 지니 고 구조적 안정성을 위해 동일 유적, 혹은 유사한 성분을 갖는 토양에서 굵은 모래의 비율이 높은 점토를 주재료로 노를 제작했을 것으로 추정된다.
따라서 송두리 유적 출토 노벽은 노가 축조된 해당 지 역의 토양을 선별하여 제작했을 것으로 보이며, 재사용을 위한 보수과정에서 기존 노벽과 유사한 특성을 갖는 토양 을 사용했을 것으로 추정한다. 또한, 점토를 주재료로 이 용하여 노를 제작하고 보수하는 초기 형태의 제철로는 중 국 내에서 3 세기까지 사용했을 것이라는 연구(Liu, 2017) 와 일치하며, 진천 송두리 유적 운영 시기를 4세기 전으로 추정하는 보고와 시기적으로 일치한다. 한반도 철기문화 는 최초로 유입된 철기류가 중국 연나라 계통이라는 점과 낙랑군의 설치 이후 한식 철기가 내려온다는 점이 중국 영향을 받았다는 근거로 활용되나, 제철기술도 중국의 직 접적인 영향을 받았다고 볼 수 있는가에 대해서는 아직 확신할 수 없는 상황이다(Kim, 2017). 본 연구로 제철기술 의 한 축인 축로기술이 중국의 영향을 받았다고 단정 지 을 순 없으나 한반도 또한 중국과 유사한 재료의 선택이 존재해, 초기 축로기술의 양상이 일치한다. 한반도 축로 기술이 중국의 발전상과 유사하게 흘러갈지 독자적인 기 술개발로 이어지는지는 추가적인 연구를 통해 확인할 수 있을 것으로 보이며 한반도 제철기술의 발전상에 대한 해 답을 줄 수 있을 것으로 기대한다. 노벽에 대한 연구는 아직 기초적이며 미답의 영역이기 때문에 본고와 같은 연 구가 축적되면 과학적이고 체계적인 접근이 가능할 것으 로 보인다.

\section{사 사}

본 연구의 시료는 중앙문화재연구원의 제공을 받았으 며 이에 감사드립니다. 


\section{REFERENCES}

Central Institute of Cultural Heritage, 2020, Songdu-ri Site, Jincheon. 5, 570-572. (in Korean)

Cheongju National Museum, 2001, Jincheon Gusan-ri Iron Production Site. 1-12. (in Korean)

Cheongju National Museum, 2004, Jincheon Seokjang-ri Iron Production Site. 227-234. (in Korean)

Cho, H.K., Cho, N.C. and Kang, D.I., 2013, Scientific Analysis of Slags and Furnace Wall collected from Iron Production Site at Suryong-ri Wonmorongi in Chungju. Journal of Conservation Science, 29, 139-147. (in Korean with English abstract)

Hong, J.H., 2015, Metallurgical study of slag from Gwanbuk-ri remains, Buyeo. Department of Cultural Heritage Conservation Science Graduate School of Kongju National University, GongJu, 1-103. (in Korean with English abstract)

Jungwon National Research Institute of Cultural Heritage, 2016, Scientific Analysis Report on the Specimens Excavated from Archaeological Iron Sites in Gyeongsang Region. 1-183. (in Korea with English abstract)

Jungwon National Research Institute of Cultural Heritage, 2018, Scientific Analysis Report on the Specimens Excavated from Archaeological Iron Sites in Jeonra Region. 1-202. (in Korea with English abstract)
Kim, S.M., 2017, Advent of Iron Making Technologies in Korea and Their Development During the Three Kingdom Period. The Trend of Iron Manufacturing Technology in Northeastern Asia, Jungwon National Research Institute of Cultural Heritage, 149. (in Korean with English)

Lee, E.W., Lee, J.J., Chae, M.H. and Kim, E.J., 2015, Examination of Smelting and Smithing Slags Excavated from the Iron Production Site of the Nogye Village. Journal of Conservation Science, 31, 411-427. (in Korean with English)

Liu, H.F., Qian, W., Chen, J.L., Chen, H.L., Matthew, L.C. and Michael R.N., 2017, Cast iron-smelting furnace materials in imperial China : Macro-observation and microscopic study. Journal of Archaeological Science, 86, 50-59. (in Engish)

Shin, J.H., 2018, Discussion on the Reexamination of Ancient Iron Production Sites in the Chungcheong Region. The Progress and Significance of Recent Excavations of Ancient Iron Production Sites in North Asia, Jungwon National Research Institute of Cultural Heritage, 152-154. (in Korean) 